\title{
Efektifitas Pembatasan Sosial Berskala Besar (PSBB) di Kota Bekasi Dalam Mengatasi COVID-19 dengan Model Susceptible-Infected-Recovered (SIR)
}

\author{
Rahmadya Trias Handayanto ${ }^{1}$, Herlawati ${ }^{2,{ }^{*}}$ \\ ${ }^{1}$ Fakultas Teknik, Universitas Islam 45; Jl. Cut Meutia No. 83, Bekasi Timur, Bekasi, \\ Jawa Barat 17113. Telp: 021-8801027, 8802015, Fax: 021-8801192; e-mail: \\ rahmadya.trias@gmail.com \\ 2 Fakultas Teknik, Universitas Bhayangkara Jakarta Raya; Jl. Raya Perjuangan, Marga \\ Mulya, Bekasi Utara, Jawa Barat 17121. Telp: 021-88955882, 889955883, e-mail: \\ herlawati@ubharajaya.ac.id \\ * Korespondensi: e-mail: herlawati@ubharajaya.ac.id
}

\begin{abstract}
To overcome the COVID-19 outbreak, the government did not carry out the lock down policy (regional quarantine policy) but implementsed the Large-Scale Social Restrictions (PSBB) policy. Starting from the capital city of Jakarta, this policy was followed by other regions. Bekasi City as a buffer zone of Jakarta immediately implemented the PSBB policy since this area is close to Jakarta and is feared to be affected by Jakarta region which is a red zone with almost half of Indonesian COVID-19 cases are in the Jakarta area. Many people do not agree with the PSBB, but in order to keep the economy growth as well as to overcome the outbreak, the government does not adopt a regional quarantine policy. To determine the effectiveness of PSBB in the city of Bekasi, this study tried to use the Susceptible-Infected-Recoverd (SIR) model to measure the spread rate of COVID-19. The results showed a decrease in the number of infected cases with beta and gamma were 0.071 and 0.05 , respectively, and the epidemic was predicted to end in June 2020.
\end{abstract}

Key word: corona virus, epidemic, pandemic, regional quarantine policy, Bekasi City

\begin{abstract}
Abstrak
Dalam mengatasi wabah COVID-19, pemerintah tidak melakukan karantina wilayah (lock down) tetapi menggunakan kebijakan Pembatasan Sosial Berskala Besar (PSBB). Dimulai dari ibukota Jakarta, kebijakan ini diikuti oleh wilayah lainnya. Kota Bekasi sebagai wilayah penyangga Jakarta segera menerapkan kebijakan PSBB mengingat wilayah ini berdekatan dengan Jakarta dan dikhawatirkan terpengaruh dengan kota Jakarta yang merupakan zona merah dengan hampir separuh kasus COVID-19 ada di wilayah Jakarta. Banyak pihak yang mendukung dan juga kurang setuju dengan PSBB, namun agar perekonomian tetap berjalan dan wabah dapat diatasi, pemerintah tidak mengambil kebijakan karantina wilayah. Untuk mengetahui efektifitas PSBB di kota Bekasi, penelitian ini mencoba menggunakan model Susceptible-InfectedRecoverd (SIR) untuk mengukur laju penyebaran COVID-19. Hasilnya menunjukan adanya laju penurunan kasus terinfeksi dengan beta dan gamma beruturut-turut sebesar 0,071 dan 0,05 dan diprediksi akan berakhir di bulan Juni 2020.
\end{abstract}


Kata kunci: virus corona, epidemik, pandemik, karantina wilayah, Bekasi City

\section{Pendahuluan}

Dalam menghambat laju penyebaran virus COVID-19 beberapa negara menggunakan cara yang berbeda, dari yang ketat seperti di China dan Italia dengan Lock Down, atau dalam peraturan perundang-undangan di Indonesia dikenal dengan istilah karantina wilayah, hingga sekedar pembatasan sosial saja seperti di Taiwan. Indonesia saat ini hanya mengedepankan pembatasan sosial saja dengan istilah Pembatasan Sosial Berskala Besar (PSBB) untuk beberapa wilayah zona merah, istilah untuk wilayah dengan sebaran COVID-19 yang tinggi seperti Jabotabek, sebagian wilayah Jawa dan Makasar.

Salah satu wilayah penyangga Jakarta adalah kota Bekasi. Wilayah ini memiliki jumlah penduduk yang besar dan banyak yang bekerja atau berinteraksi dengan kota Jakarta. Mengikuti Jakarta yang telah menerapkan PSBB, wilayah ini juga menerapkan PSBB yang dimulai pada tanggal 15 April 2020 dan diperpanjang hingga akhir Mei 2020. Berbeda dengan karantina wilayah atau lock down, PSBB masih membolehkan aktivitas ekonomi agar roda perekonomian tetap berjalan, walaupun banyak pembatasan khususnya untuk pengendara roda dua yang dibatasi hanya satu orang saja.

Banyak pihak yang mempertanyakan efektifitas PSBB baik dari kalangan pendukung karantina wilayah maupun yang anti PSBB. Penelitian ini mencoba menjawab hal tersebut dengan menggunakan model sebaran Susceptible-Infected-Recoverd (SIR) yang telah dikombinasikan dengan pencocokan (curve fitting) dengan metode kurva logistik (Batista, 2020; Choisy, Gugan, \& Rohani, 2007; Cooke \& Van Den Driessche, 1996; Herlawati, 2020; Kilbourne, 2006; Mummert \& Otunuga, 2019; Nuraini, S, \& Apri, 2020). Model tersebut dijalankan selama pelaksanaan PSBB di Kota Bekasi dari tanggal 15 April hingga awal Mei 2020.

Selain membahas efektifitas penerapan PSBB, model SIR tersebut digunakan juga untuk memprediksi berakhirnya wabah pandemi virus COVID-19 di Kota Bekasi (Ariawan, Riono, Farid, \& Jusril, 2020).

Walaupun model-model lain banyak bermunculan seperti SEIR, dengan tambahan E yang berarti Exposure, model SIR diterapkan pada penelitian ini dengan dilengkapi pencocokan kurva guna meminimalisir kesalahan (error) yang terjadi mengikuti pergerakan kasus COVID-19 selama masa PSBB.

\section{Metode Penelitian}

COVID-19 merupakan kasus pandemik yang menyebar lintas benua. Namun model persebarannya mengikuti pola epidemik. Salah satu model penyebaran epidemik adalah model 
Susceptible-Infected-Recovered (SIR). Model ini membagi data sebaran menjadi tiga yaitu populasi yang berpotensi terinfeksi (susceptible), populasi yang terinfeksi (infected) dan populasi yang sembuh (recovered). Secara umum persamaan SIR dapat dilihat pada persamaan (1) - (3) berikut (Choisy et al., 2007):

$$
\begin{aligned}
& \frac{d S}{d t}=-\frac{\beta}{N} I S \\
& \frac{d I}{d t}=\frac{\beta}{N} I S-\gamma I \\
& \frac{d R}{d t}=\gamma I
\end{aligned}
$$

Dimana $t$ adalah waktu, $S(t)$ jumlah populasi yang berpotensi terinfeksi, I(t) jumlah orang yang terinfeksi, dan $\mathrm{R}(\mathrm{t})$ jumlah orang yang sembuh.

Data kasus terinfeksi di Kota Bekasi dapat dilihat pada Tabel 1. Sekilas tampak adanya fluktuasi namun di awal Mei cenderung tetap. Data tersebut akan dimasukan ke model SIR dengan pencocokan kurva logistik. Metode ini dikembangkan oleh Milan Batista dan sudah banyak digunakan untuk memprediksi selesainya wabah pandemi COVID-19 di seluruh negaranegara di dunia.

Beberapa asumsi perlu divalidasi karena sangat mempengaruhi hasil akhir prediksi, seperti akurasi data apakah benar-benar diperoleh oleh setiap negara. Sebab jika banyak kasus yang tidak terdeteksi akan mengakibatkan akurasi prediksi kurang tepat. Dalam penelitian ini diasumsikan kota Bekasi sudah baik dalam melakukan pendataan kasus COVID-19 baik melalui pemantauan Orang Dalam Pengawasan (ODP) maupun lewat rapid-test yang rutin dilaksanakan.

Tabel 1. Sebaran COVID-19 di Kota Bekasi Selama PSBB

\begin{tabular}{cc}
\hline Hari/Tanggal & Jumlah Kasus \\
\hline $15-A p r$ & 175 \\
\hline $16-A p r$ & 183 \\
\hline $17-A p r$ & 189 \\
\hline $18-A p r$ & 192 \\
\hline $19-A p r$ & 195 \\
\hline $20-A p r$ & 203 \\
\hline $21-A p r$ & 214 \\
\hline $22-A p r$ & 219 \\
\hline $23-A p r$ & 225 \\
\hline $24-A p r$ & 229 \\
\hline $25-A p r$ & 229 \\
\hline $26-A p r$ & 234 \\
\hline $27-A p r$ & 244 \\
\hline $28-A p r$ & 248 \\
\hline $29-A p r$ & 248 \\
\hline
\end{tabular}




\begin{tabular}{cc}
\hline Hari/Tanggal & Jumlah Kasus \\
\hline 30-Apr & 248 \\
\hline *Populasi: & 3.083.644 Jiwa
\end{tabular}

Sumber: Hasil Penelitian (2020)

Penelitian ini diasumsikan kota Bekasi sudah baik dalam melakukan pendataan kasus COVID-19 baik melalui pemantauan Orang Dalam Pengawasan (ODP) maupun lewat rapid-test yang rutin dilaksanakan.

Untuk menjalankan model SIR dalam penelitian ini digunakan software MATLAB 2017 yang berjalan dalam sistem operasi Windows 10 Professional.

\section{Hasil dan Pembahasan}

Selain dengan memprediksi parameter-parameter dalam model SIR yang berupa beta dan gamma, prediksi dapat juga menggunakan sebaran kasus terinfeksi yang real. Sebaran tersebut dengan pencocokan kurva logistik akan diperoleh beta dan gamma yang sesuai.
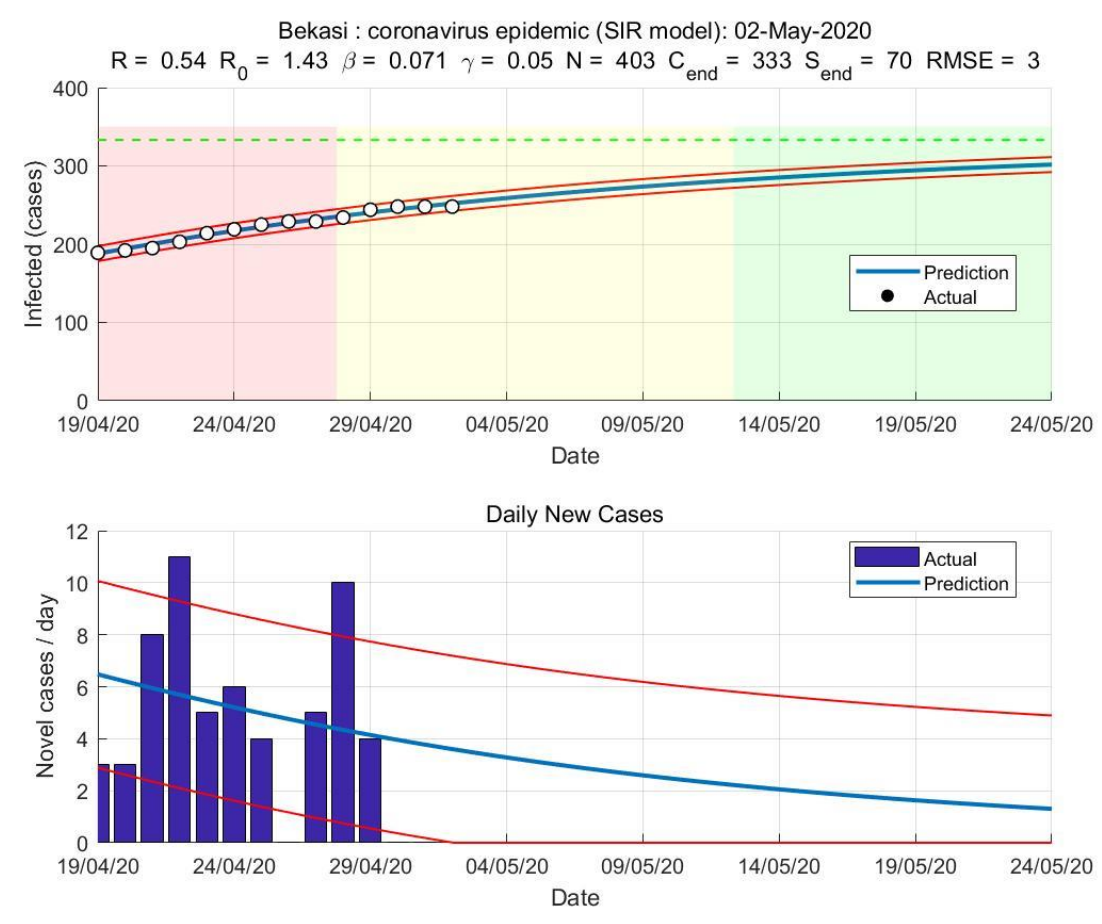

Sumber: Hasil Penelitian (2020)

Gambar 1. Metode SIR untuk rentang PSBB kota Bekasi tanggal 15 April - 2 Mei 2020

Gambar 1 menunjukan hasil prediksi SIR dengan pencocokan kurva logistik. Kurva prediksi menunjukan penurunan dari awal pelaksanaan PSBB hingga diperkirakan COVID-19 berhenti di bulan Juni. Parameter yang dihasilkan adalah peluang terinfeksi beta sebesar 0.071 dan peluang sembuh gamma sebesar 0.05 . 
Untuk mengetahui efektifitas pelaksanaan PSBB di Kota Bekasi ada baiknya kita bandingkan dengan kota lain yang juga melaksanakan PSBB, misalnya DKI Jakarta, seperti ditunjukan pada Gambar 2.
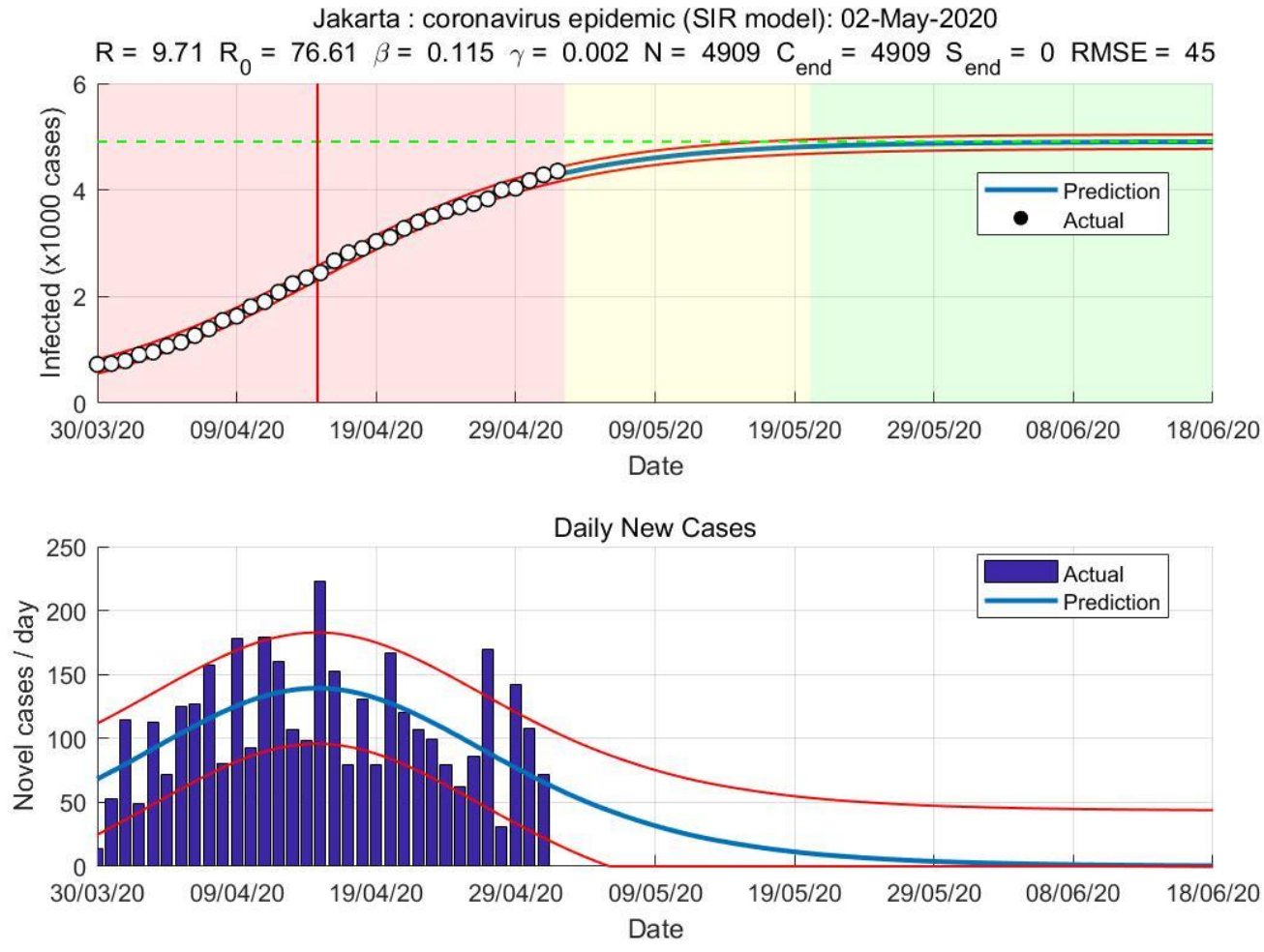

Sumber: Hasil Penelitian (2020)

Gambar 2. Model SIR Kota Jakarta

Kota Jakarta tampak lebih baik penurunannya dibanding Kota Bekasi. Hasil prediksi dengan SIR menunjukan wabah COVID-19 akan berakhir di akhir Juli 2020. Namun tidak terlalu jauh dengan kota Bekasi, disamping memang DKI Jakarta lebih dahulu melakukan PSBB disamping hal-hal lain yang mengurangi laju peluang terinfeksi seperti rapid-test dan pemantauan ODP.

\section{Kesimpulan}

Hasil simulasi dengan Model SIR menunjukan adanya laju penurunan kasus COVID-19 di Kota Bekasi. Hal ini menunjukan efektifitas yang baik dari penerapan PSBB di kota tersebut, begitu juga efektifitas di wilayah lain yang telah menerapkan PSBB sebagai pembanding, misalnya Kota DKI Jakarta. Hal-hal lain tentu saja masih perlu dikaji mengiringi kebijakan PSBB seperti masalah ekonomi, sosial, dan budaya. Namun perlu tetap mempertahankan pengawasan ketat terutama ketika mulai beralih dari PSBB menjadi kebijakan dalam kondisi normal. 


\section{Daftar Pustaka}

Ariawan, I., Riono, P., Farid, M. N., \& Jusril, H. (2020). COVID-19 Modelling Scenarios Indonesia. Jakarta.

Batista, M. (2020). Estimation of the final size of the coronavirus epidemic by the logistic model. MedRxiv, 1-12.

Choisy, M., Gugan, J.-F., \& Rohani, P. (2007). Mathematical Modeling of Infectious Diseases Dynamics. Encyclopedia of Infectious Diseases, 379-404. https://doi.org/10.1002/9780470114209.ch22

Cooke, K. L., \& Van Den Driessche, P. (1996). Analysis of an SEIRS epidemic model with two delays. Journal of Mathematical Biology, 35(2), 240-260. https://doi.org/10.1007/s002850050051

Herlawati. (2020). COVID-19 Spread Pattern Using Support Vector Regression. PIKSEL: Penelitian IImu Komputer Sistem Embedded and Logic, 8(28), 67-74.

Kilbourne, E. D. (2006). Influenza pandemics of the 20th century. Emerging Infectious Diseases, 12(1), 9-14. https://doi.org/10.3201/eid1201.051254

Mummert, A., \& Otunuga, O. M. (2019). Parameter identification for a stochastic SEIRS epidemic model: case study influenza. Journal of Mathematical Biology, 79(2), 705-729. https://doi.org/10.1007/s00285-019-01374-z

Nuraini, N., S, K. K., \& Apri, M. (2020). Data dan Simulasi COVID-19 dipandang dari Pendekatan Model Matematika Akumulasi kasus COVID-19 : Italia. 